\title{
ACTORS, ACTANTS, AUDIENCES, AND ACTIVITIES IN CROSS- MEDIA NEWS WORK
}

\author{
A matrix and a research agenda
}

\section{Seth C. Lewis and Oscar Westlund}

Original citation: Lewis, S. C., \& Westlund, O. (2014). Actors, actants, audiences, and activities in cross-media news work: A matrix and a research agenda. Digital Journalism. doi:10.1080/21670811.2014.927986

This is the preprint version of an article published in Digital Journalism. The final version of the article can be found via

http://www.tandfonline.com/doi/full/10.1080/21670811.2014.927986

\begin{abstract}
In contemporary journalism, there is a need for better conceptualizing the changing nature of human actors, nonhuman technological actants, and diverse representations of audiences-and the activities of news production, distribution, and interpretation through which actors, actants, and audiences are inter-related. This article explicates each of these elements-the Four A's-in the context of cross-media news work, a perspective that lends equal emphasis to editorial, business, and technology as key sites for studying the organizational influences shaping journalism. We argue for developing a sociotechnical emphasis for the study of institutional news production: a holistic framework through which to make sense of and conduct research about the full range of actors, actants, and audiences engaged in cross-media news work activities. This emphasis addresses two shortcomings in the journalism studies literature: a relative neglect about (1) the interplay of humans and technology, or manual and computational modes of orientation and operation, and (2) the interplay of editorial, business, and technology in news organizations. This article's ultimate contribution is a cross-media news work matrix that illustrates the interconnections among the Four A's and reveals where opportunities remain for empirical study.
\end{abstract}

KEYWORDS cross-media news work; digital media; journalism studies; news institutions; sociotechnical emphasis; technology 


\section{Introduction}

Amid the widespread diffusion of digital information technologies, the mediascape is changing in various ways. Perhaps most visibly among these changes, new configurations involving social actors, technological actants, work-practice activities, and different kinds of audiences have become interlinked in ways that confound boundaries between production and consumption, professional and nonprofessional, and intra- and extra-organizational domains. Thus, the nature of who or what-whether human actor or nonhuman technological actant-guides message formation and circulation, and how such media-shaping takes place in relation to whom (certain kinds of audiences), may require some rethinking.

For the study of institutional news production particularly and news work more generally, there is a scholarly need for theoretical frameworks that accommodate and account for the shifting character of these elements and the interconnections among them: human actors (e.g., journalists, technology specialists, and businesspeople); technological actants (e.g., algorithms, networks, and content management systems); and audiences (e.g., assemblages of audiences distinct to certain platforms, devices, or applications) -all potentially intertwined in the activities that constitute cross-media news work. The term cross-media refers to the integration of multiple media platforms. When combined with news work, the concept acknowledges the various forms of journalism within a holistic framework-including editorial as well as business and technology activities, thus rendering a more complete picture of news publishing at the organizational level (Westlund 2011).

In reviewing the literature on actors, actants, audiences, and activities, we argue that there is a lack of comprehensive theorizing that acknowledges these dimensions and their inter-relatedness in contemporary cross-media news work. This article's contribution is in explicating the Four A's, introducing a matrix for visualizing their relationships, and proposing a research agenda for studying them in a more holistic fashion. Our overall purpose is to develop a heuristic for conceptualizing news production and distribution-and yet, the matrix we propose likewise could be applied to contexts of media creation and circulation more generally.

\section{Toward a Sociotechnical Emphasis in Journalism Studies}

During the past two decades, journalism studies scholars have paid special attention to the role of technology in news work (for reviews, see Domingo and Paterson 2011; Mitchelstein and Boczkowski 2009; Steensen 2011). This research has typically drawn upon established theories and concepts for explaining how various elements of technology have been incorporated into (or resisted by) the professional cultures and organizational contexts of journalism (Lewis 2012). These approaches have been helpful in clarifying the changing character of digital news production and the evolving relationship that journalists have with audiences (e.g., Singer et al. 2011). Yet, this line of research has given greater emphasis to human-centric considerations-such as individual role conceptions, organizational constraints, professional norms, national culture or ideology, and other socio-cultural factors-without sufficiently acknowledging the distinct role of technology and the inherent tension between human and machine 
approaches (exceptions include Anderson 2013 and Boczkowski 2004). This humantechnology tension is best understood as a continuum between manual and computational modes of orientation and output in contemporary cross-media news work-a way of perceiving the relative gravitational pull of each dimension in shaping news publishing (Westlund 2013).

Additionally, this vein of journalism studies has focused heavily, if not exclusively, on the editorial sides of news organizations. The result has been neglect in the literature for socio-technical objects and information technology specialists (exceptions include Ananny 2013 and Nielsen 2012), particularly when such technologies and technologists operate beyond the boundaries of the organization. Even in recent studies of computer programmers and related technical specialists, scholars have prioritized the study of editorial implications vis-à-vis a broader reading of organizational change (e.g., Karlsen and Stavelin 2014; Parasie and Dagiral 2013). This emphasis is understandable: editorial actors are most associated with shaping media content and its downstream impact on media audiences. Nevertheless, we argue alongside media management scholars that business elements are no less crucial to the overall framework of institutional news production.

Because of these blind spots in the literature-of failing to account more fully for the human-technology dynamic on the one hand, as well as the organizational interplay of editorial, technology, and business on the other-there is an opportunity for developing a sociotechnical emphasis in journalism studies. This emphasis is not a deterministic view that assumes technology is "changing" journalism; on the contrary, by bringing to the fore technologies and technologists as key aspects of study, this approach adds a sociotechnical focus to the ongoing sociocultural research being done about journalism, helping to reveal nuances in the relationships among human actors inside the organization, human audiences beyond it, and the nonhuman actants that cross-mediate their interplay. Additionally, this sociotechnical emphasis acknowledges the extent to which contemporary journalism is becoming interconnected with technological tools, processes, and ways of thinking as the new organizing logics of media work (Deuze 2007; Lewis 2012).

Our point of departure is to clarify the larger set of dynamics operating in the human-technology and editorial-business-technology intersections to facilitate a matrix and a research agenda for cross-media news work. We do this by explicating actors, actants, audiences, and activities, in each case describing what we know from extant literature and thereafter suggesting how a sociotechnical emphasis might shed new light on these elements and their relationships.

\section{Actors, Actants, Audiences, and Activities}

\section{Actors}

Humans play a central part in shaping media. Sociologically minded scholars have emphasized the social construction of technology and user agency in assessing the "impact" of tools (Boczkowski 2004; Pinch and Bijker 1984). Nevertheless, scholars of communication and technology have concluded that in all but dismissing technological determinism entirely "we may have 'overcorrected"' (Neff et al. 2012, 300), privileging human power to the point of failing to account for the obvious in 
contemporary media life: "there are times and places when and where we are not fully in control of our machinescapes" (312). The upshot, Neff and colleagues suggest, is to acknowledge "technical agency," not in assigning consciousness to technology but in recognizing the constraints that humans may face in working within technical systems of ever-growing complexity and ubiquity.

How might this apply to a study of humans working within cross-media news work? For one, journalists have long worked with both machines (technology) and machine-operators (technicians) to accomplish journalism: from lithographs to typewriters to newspaper pagination to early online journalism to content management systems (CMS). There is nothing inherently new about what Powers $(2012,25)$ calls "technologically specific forms of work"-forms of news work that are inextricably tied to the technologies associated with them. What is important to recognize, however, is that such forms of work, from photojournalism of yore to programmer-journalism of today, carry certain assumptions about their journalistic legitimacy. To the extent that a news practice is distinctly connected to a technical affordance, it may struggle, at least in an early stage, to be recognized as "real" or simply "ordinary" journalism (Powers 2012). Perhaps journalists discount technically enabled forms of journalism because of their conviction that reporting - a most human endeavor-is central to their professional craft (Anderson 2013). Indeed, historically the broad work of news publishing-the contentcentric work of editorial-has carried a manual orientation: journalists and editors manipulated comparatively "dumb" tools to manufacture news information. Digitization, however, has brought with it a variety of technologically specific forms of work, such as social media curation and online aggregation, as well as "smart" algorithms and automated processes that in some instances can replace activities previously performed by humans-typified by the emergence of "robot journalism" and its machine-written forms of news (van Dalen 2012). While many media scholars have directed attention to the increasingly precarious conditions of news workers because of institutional and organizational pressures, less research has focused squarely on the human-technology dimension as an organizing framework. Future research might therefore investigate how editorial workers are negotiating issues of authority, identity, and expertise in connection not only with technologically specific forms of work like programmer-journalism (Lewis and Usher 2013; Parasie and Dagiral 2013) but also with the machine-led processes assuming more responsibility for functions traditionally associated with professional control (Bakker 2012; Lewis 2012; Westlund 2011).

Beyond simply recognizing the interplay of journalists and technology on the editorial side, however, a sociotechnical emphasis would also address the roles of other actors, within and beyond the news organization. External to the firm, there are several actors that reasonably play a shaping role-from sources and advertisers, to policymakers and hardware/software providers. Here we wish to focus on two internally situated social groups that historically have been less visible to media researchers and yet are no less relevant in media organizations: technologists and businesspeople. It is crucially important to acknowledge these actors, in both theory and empirical practice, if we are to grasp contemporary changes in news media from an organizational perspective.

The first group of actors would include information technology (IT) specialists, systems designers, project managers, information architects, product developers, and other programming technicians-some working on editorial-facing news applications, 
some working on business-facing products and services, and others working across departments to support the overall systems of digital production and distribution. Looking at the editorial angle in particular, researchers are only beginning to account for the rise of computational journalism (Anderson 2012) and its diverse manifestations in form and content (Gynnild 2013), as programmers, hackers, and web developers play an increasingly central role in new and legacy media organizations (Lewis and Usher 2013; Parasie and Dagiral 2013).

The second group of actors, businesspeople, would include marketers, sales associates, customer relationship managers, analysts specialized in big data and behavioral targeting, and others connected with supporting the bottom line of the crossmedia enterprise. It likewise could include hybrid arrangements between business and technology, such as data science teams that analyze traffic patterns to help optimize the

revenue potential of paywalls and mobile apps. Neither technologists nor businesspeople have received adequate attention in the literature on technological adoption, appropriation, and innovation in journalism. Journalism researchers typically have focused on journalists and their norms and practices (e.g., Domingo and Paterson 2011). Meanwhile, scholars of media management and economics have focused on commercial managers (e.g., Küng 2008). Technologists, in both streams of research, have been mostly "black-boxed" (Latour 1987)—disregarded as key objects of study because they reside so thoroughly in the background. A research opportunity lies in stitching these domains together in a more holistic study of cross-media news work, acknowledging the social construction of technology through the interplay of editorial, technological, and business interests, as Nielsen (2012) did in his study of blogging in legacy news organizations and Westlund $(2011 ; 2012)$ demonstrated in his analyses of mobile news development.

Finally, this sociotechnical emphasis would also recognize the ways in which technologists are mediating growing forms of cross-awareness and coordination between the editorial and business sides, through the co-development of information products and services for multiple platforms. For example, in what sense have technologists facilitated, if not directed, different projects and outcomes, given their distinct communities of practice, cultural norms, and perceptions of the audience as active participants rather than as commodities or relatively passive recipients? (cf., Lewis and Usher 2013; Nielsen 2012). Additionally, at the intersection of these actors, what might contemporary research reveal about the social shaping of native advertising, branded content, and other experiments in new revenue streams to underwrite traditional news work? Situating human actors in relation to technological actants may help to ground such a research approach.

\section{Actants}

The term actants, as we define it, refers generally to material objects that are notable for their association with human actors and the activities they undertake in conjunction with such objects. We invoke the term carefully but purposefully. We recognize that in the context of actor-network theory (ANT), a sociological and methodological approach concerned with tracing associations ("following the actors to where they lead the researcher," in the common refrain), the term actant may refer to any actor, human or nonhuman, that is engaged in a networked system under scrutiny. 
Indeed, ANT adherents typically eschew most a priori categories altogether, allowing the determination of actors/actants and their relative influence in the network to emerge organically and situationally (Couldry 2008; Plesner 2009). ANT does not erase distinctions between human and nonhuman, but neither does it privilege one over the other in assessing the relative "force" through which the social or the technological determines outcomes. As Latour $(2005,71)$ notes, "the questions to ask about any [actant] are simply the following: Does it make a difference in the course of some agent's action or not?" Thus, in this discussion of technological actants in activities of crossmedia news work, the question would become: Does a technological object like a content management system (CMS), application programming interface (API), or set of software code make a difference in the course of some actors' activities or not?

ANT therefore serves a key purpose in highlighting the relevance and role of nonhuman actors. Yet, even as we draw upon ANT, we also depart from it in articulating a sociotechnical emphasis that (1) acknowledges there are a variety of increasingly significant nonhuman actants distinct from human actors, here defined as technological actants, and (2) treats certain categorizations-such as journalism, technology, and business, and the Four A's themselves-as analytically useful and indeed necessary for the study of institutional news production. We take as a starting point that the technological actants described here are inscribed and instructed by humans, socially constructed to suit journalistic, commercial, and technological purposes within news organizations. It is in this social framing process, for instance, that CMS technology are encoded with journalistic news values in their DNA, determining how particular types of content are selected for publication across particular platforms; and that computational exploration in journalism-with its multifaceted interplay of data, social science, and storytelling-depends more on distinct human direction than the technology per se (Gynnild 2013). Such a perspective, borrowing from ANT but not necessarily being limited to it, may bring to the forefront those underlying technological actants and their networked relationships with human actors-things that have long been missing in journalism and media studies literatures more focused on sociocultural explanations (Schmitz Weiss and Domingo 2010). Such a gaze, for example, brings forward an appreciation for new configurations of "newsware" (Ananny 2013): networks of technological actants like interfaces and algorithms, as well as cultural norms and practices connected to them.

Few studies have attempted to understand why some technological assets are embraced in journalism while others are not (Steensen 2011). To understand the "potential" for, and application of, such assets in journalism requires a more focused perspective on the technological actants that would facilitate them. Put another way: Answering Latour's "does it make a difference?" question becomes difficult when the journalism studies literature has neither thoroughly identified the "it" (actant) in question nor the full array of contextual influences connected with its supposed differencemaking. While there is a vibrant subset of media studies that uses ANT to study journalistic change (e.g., Hemmingway 2008; Micó et al. 2013; Plesner 2009; Schmitz Weiss and Domingo 2010; and Primo and Sago, and Domingo, Masip and Costera Meijer elsewhere in this special issue), there remains an opportunity to better account for the particular place of technological actants vis-à-vis the entire organizational assemblage of journalists, businesspeople, and technologists. 
Moreover, a research approach that puts technological actants on par with actors in cross-media news work would further our understanding about the relative influence of technology vis-à-vis humans (cf., Westlund 2013), whether internal or external to the news organization. The internal dimension is easy to imagine: e.g., the email (Plesner 2009), CMS (Schmitz Weiss and Domingo 2010), and related technologies that are inward-facing technological actants from the perspective of cross-media news workers. The external dimension might be understood as the growing variety of computational programs designed to capture and reconfigure information streams produced by news organizations, re-presenting them for audiences. Examples of this would include mobile and tablet applications such as Flipboard, Zite, and Facebook Paper, driven by automated forms of personalized content packaging - as well as websites that specialize in digital aggregation, incorporating a hybrid of actant- and human-led filtering and publishing, on sites like Techmeme and Mediagazer. Situated betwixt the internalexternal dynamic are APIs, which function as go-between interfaces that, with permission, allow outside computer programmers to access and build upon the information resources from a provider. In the context of news work, researchers are only beginning to unpack how APIs might function as interstitial technological actants facilitating the likes of business model innovation (Aitamurto and Lewis 2013) or reconfigured relationships with the public sphere (Ananny 2013). Ultimately, future research should acknowledge the significance of actants and their functionalities, their organizational implications, and the consequences of their internal or external placement and purpose.

\section{Audiences}

The very notion of "audience" and the passivity associated with that term has long been a contested concept, with audiences variously imagined as commoditized recipients or active meaning-makers in the process of media consumption (Bolin 2012; Hagen and Wasko, 2000). Napoli (2010) argues that we are not witnessing the end of audiences, but rather an evolution in how they are understood by media institutions. In a "post-exposure audience marketplace," when metrics of audience exposure are being replaced by more fine-grained assessments of consumers' preferences, clicks, and engagement, audiences are being rationalized through massive data tracking (Napoli, 2010) - and, at the same time, recognized for their increased autonomy and creative potential (Anderson 2011). Thus emerges certain tensions about how audiences are conceived from the standpoint of media organizations: as relatively passive recipients in the traditional mass media sense, as statistically aggregated commodities for media advertisers, or as active participants in cultural production. Within the media organization, these perceptions of the audience may be represented in distinct ways: Journalists, known to care little about understanding the audience (Gans 1979), may be inclined to see them as (mostly passive) recipients of information professionally vetted for them. Businesspeople may predominantly take a commodity view, which goes handin-hand with tracing and capitalizing on digital footprints made readily available even while also recognizing the audience's utility in making media content viral and "spreadable" (Jenkins, Ford, and Green 2013)—and thereby more marketable. Technologists, meanwhile, may primarily see audiences as potentially active participants in the spirit of open source (Lewis and Usher 2013). These competing 
conceptualizations of the audience, while tentatively constructed here, can begin to illustrate not only how audiences are framed by different institutional actors, but also how certain framings may exert influence on others. For instance, if journalists begin minimizing their view of audiences as passive, they may do so in the direction of a market logic (e.g., commodities) and/or a participatory logic (e.g., active participants). ${ }^{2}$

The first of these perspectives-audiences as recipients-is both intuitively recognizable within traditional models of mass communication (e.g., Westley and MacLean 1957) and also thoroughly contested as a "historical fallacy" (e.g., van Dijck 2009). While the relatively activity or passivity of such a receiving role is the subject of great debate (see Bolin 2012), the salience for this discussion is in representing audiences as publics intended to be informed through news. Such a conceptualization suits journalism's normative function as public monitor. As such, even while increasingly aware of the audience and its expressive capabilities online, journalists still find much of their professional purpose in imagining the audience as recipients who depend on them for news (Anderson 2013). Thus "[audiences] are still, overall, receivers of information created and controlled by the journalist" (Singer et al. 2011: 189).

Seeing audiences as recipients, however, is not the same as seeing them as commodities, the second of the perspectives noted above. Political economists were early in arguing that mass media audiences were packaged as products sold to advertisers (Smythe 1977). Such discussions have gained traction again in the $21^{\text {st }}$ century (Turow 2011), as cruder measures of media exposure give way to more sophisticated, data-intensive audience information systems that allow media firms and advertisers to determine not only who has consumed which pieces of content but also predict future content preferences, tailor content for particular individuals, and gather behavioral responses to content exposure (Napoli 2010). These approaches have raised concerns about privacy, particularly in light of revelations about institutionalized spying on individuals' digital traces. Of course, the business model behind many legacy news media relies on the commodification of audiences, and in the instance of newspapers, has also involved charging for content from these audiences. Picard and Westlund (2012) suggest that newspapers traditionally took a producer-centric approach, meaning that their actors predominantly relied on professional values for judgments, hardly bothering to understand their audiences. Such reliance on gut feelings about what audiences needed, rather than what they wanted, has been a consistent theme in the literature on journalists' relationship with audiences (Boczkowski and Mitchelstein 2013). However, and in conjunction with the trends in digital audience metrics noted above, news media have since developed a consumer-centric approach (Picard and Westlund 2012), one that more readily tries to understand and please audiences and advertisers, and thus treats audiences as commodities. Actors in news media organizations thus have mobilized more and more resources, including technological actants that enable continuous measurement, analysis, and commercialization of audiences.

Turning to research on audiences as active participants, the rise of interactive, user-directed, and social media has led to a paradigmatic shift in scholarly attention to audiences (Jenkins et al. 2013). Emblematic of this turn, Bruns (2012) has introduced the concept of produsers to reflect how audiences play dual roles as producers and users of media. Exploring the relationship between journalism and active audiences, most research has suggested that legacy news media resist rather than embrace such participation. Journalists typically see users as "active recipients" who are encouraged to 
react to journalists' work but not contribute to the actual process of its creation (Singer et al. 2011). Nevertheless, some news media have taken a participation-centric approach, attempting to involve their audiences in activities of journalism as well as business and technological innovation (Picard and Westlund 2012). As technologists playing a growing role in media organizations, some of this openness may be associated with the participatory logic of digital media (Lewis 2012) that is more readily embraced by technologists than journalists (Parasie and Dagiral 2013).

Audiences thus may be simultaneously treated as recipients, commodities, and active participants by news media, thereby serving normative, commercial, and cultural functions alike. In drawing out a multi-faceted perspective on audiences, Anderson (2011) argues that a distinction between "audience ignorance" and "audience responsiveness" on the part of journalists is a false one, complicated by the emerging role of the algorithm-an actant that plays a mediating role among journalists, news products, and audiences. Algorithmic journalism, he argues, diminishes distinctions between human and nonhuman forms of data and judgments, appropriating massive volumes of audience signals to steer content creation and circulation in the service of consumer preferences. The precise nature of the algorithms involved, and the implications for journalism and public knowledge that they entail, have yet to be examined.

More broadly, the role of actants at the intersection of actors and audiences in cross-media news work deserves greater scrutiny. Whether visible or invisible to endusers, technological actants intermediate relationships of production, distribution, and consumption-from systems for authentication, behavioral tracking, algorithmic personalization, APIs for content streams, social media platforms, and on and on. There are crucial matters of editorial, business, and technology practice connected to the pursuit of audiences through various technological actants: On the journalism side, the growth in job roles specifically focused on search engine optimization (SEO) and social media optimization (SMO). On the business side, the growth in capturing and crunching "big data" metrics on site visits, time-on-page, and drop-off rates-both to enhance advertising muscle and improve return-on-investment (ROI), and to better predict the future news preferences of distinct audiences. On the technology side, the growth in interactive applications that begin to shift the orientation from audience-as-recipient to audience-as-participant, consistent with technologists' preferred view (cf., Nielsen 2012). While having a relative competitive advantage in their access to data about people in the "offline" world, news media still remain far behind the visitor-tracking power of the likes of Google and Facebook-but the seemingly inexorable trend in that direction calls for research scrutiny that considers the entirety of actors and technological actants engaged in representing audiences in a cross-media context.

\section{Activities}

Media activities are synonymous with routinized practices that, in connection with social and material resources and contexts, give shape to media messages and their construction and subsequent circulation and reception (Couldry 2012). In the context of media organizations, such activities are the patterns of action through which an organization's institutional logic is made manifest through media. In that light, this article 
has encouraged scholars to adopt a more holistic, sociotechnical emphasis to crossmedia news work activities.

Turning now to the specific activities in which actors, actants, and audiences are mutually engaged, Westlund's (2013) model of journalism provides a useful framework. It illustrates how various media activities-whether editorial or non-editorial, manual or computational, in orientation-fall on a continuum between repurposing and customization (creation and/or adaptation). Attempting here to first contribute to the journalism studies literature, we give priority to exemplifying the dynamic interplay of actors, actants, and audiences in journalistically oriented activities.

Journalism has largely been treated as a routinized media practice, one with institutionalized patterns of professional roles, working rules, and shared principles. While journalism has a distinct occupational ideology (Deuze 2005) and professional logic (Lewis 2012), its information processes are similar to communication practices that have long existed in complex societies, where the need to communicate across time and space, whether in a mass or interpersonal fashion, has been necessary for social function (Domingo et al. 2008). Nor are journalism's routines entirely static, as they evolve to accommodate new arrangements with actors and technological actants. Domingo and colleagues (2008) conceptualized these institutionalized communications functions in five stages of news production: access and observation, selection/filtering, processing/editing, distribution, and interpretation. They used that analytical framework to evaluate the relative openness of newspapers to citizen participation. Placing their findings in the context of this article, journalistic actors were found reluctant to relinquish their professional control to the audience, and technological actants-in this case, the structural components of news websites-offered little opportunity for audiences to contribute. Journalists remained in charge of decision-making along all five stages, and seemingly only invited audiences to participate in interpretation. This was facilitated by technological actants supporting online comments and forum discussions. Domingo et al. (2008) acknowledge that this likely has changed since their study in 2007.

\section{The Cross-Media News Work Matrix: Bringing Actors, Actants, and Audiences Together}

The activities carried out in each of those five stages have an influence on the degree to which news is customized or repurposed. Attempting to explicate this further in light of the Four A's, we propose The Cross-Media News Work Matrix (see Table 1), which synthesizes these five stages of journalistic activities in relation to actors, actants, and audiences. Following our previous discussions, actors are grouped into journalists, technologists, and businesspeople; actants are distinguished by their internal or external placement relative to the media firm; and audiences are classified as recipients, active participants, and commodities.

The journalist actors naturally bear primary significance because this classification focuses on activities assumed to be mainly journalistic. Thus, our discussions will give emphasis here to how and why other actors, as well as actants and audiences, might be involved in these activities. Three criteria have been used for the assessment of each party's potential involvement in each respective stage: (1) their capability (i.e., 
competences and affordances), (2) their willingness (i.e., values and interests), and (3) their frequency of involvement (i.e., recurrent rather than sporadic).

[Insert Table 1 here]

\section{Access/Observation}

Technologists and actants may be reasonably assumed to accompany journalists in gaining access to and making observations of events and information. Technologists assist journalists in adopting and modifying technological tools (actants) that serve purposes of securing source material or detecting patterns. For instance, computer scripts can help journalists scrape online information for data journalism, and increasingly precise tools facilitate the real-time analysis of the audience sentiment across the Web and social media (cf., Godbole et al. 2007). The data retrieved and presented by technological actants to journalists may help identify potentially worthwhile topics for future stories, leading to the algorithmic journalism described by Anderson (2011). Even in a less quantitative sense, social media platforms, as key technological actants in news work, serve as "ambient" awareness systems (Hermida 2010), allowing publics to more readily observe the zeitgeist of a particular moment or event, and enabling more reciprocal forms of information exchange between journalists and audiences (Lewis, Holton, and Coddington 2014). By its very sociotechnical and sociocultural framework, Twitter has been found to facilitate the potential for new patterns in news sourcing as journalists use it to access, observe, and act upon the opinions not only of elites but also alternative actors engaged in public discussion (Hermida, Lewis, and Zamith 2014). News media may develop architectures that enable sophisticated measures of audience-tracking that feed into the access/observation stage of journalism. Besides these measurement-oriented technological actants residing inside of news media, external providers like Google Analytics or global data and insight consultancies like Kantar also provide relevant technological actants.

To date, however, most scholarly attention has been given to outlining the role of audiences as active participants in the access/observation stage-in the form of eyewitness accounts, photos/videos, source material, and so on (e.g., Singer et al. 2011). The development of technological actants has done much to facilitate journalistic interactions with audiences in this data-gathering phase. To cite just one example: Aftonbladet, the largest Swedish evening tabloid newspaper, launched new functionalities in 2012 for its mobile-based participatory journalism interface. Citizens have been recruited into a panel allowing Aftonbladet to trace their GPS-position around the clock, and also facilitate contact with them whenever desired. When journalists are notified about an ongoing event by their actants following news wires and police communication, such as an ongoing robbery in a suburb, they can ask their actant to identify which members of their active audience are within close proximity of the event. Moreover, the journalistic actors can exchange interpersonal messages with their active audience, who in turn can utilize their mobile device to take pictures, record videos, and immediately transmit this data to the journalists. With origins in telecommunications and computing, contemporary smartphones provide affordances for participation, seemingly without spatial and temporal limitations (cf., Westlund 2013). 


\section{Selection/Filtering}

Domingo and colleagues (2008) concluded that journalists were in exclusive control of this stage. Research has documented how newsrooms, with inherent hierarchies, have secured professional control of selection and filtering (Tuchman 1978). Technologists and businesspeople have historically been unwelcomed to exert much influence on the activities taking place in this stage. Nevertheless, as the editorialbusiness wall becomes more porous in a metric-driven environment, businesspeople presumably could have a say in the themes and topics their newsrooms address to attract audiences (as commodities) - though there is insufficient evidence that this is yet happening broadly. More likely is the influence that technologists may have when working in teams with journalists, proposing opportunities for developing news themes and topics as represented via digital technologies and interfaces-like the "Snow Fall" interactive feature co-developed by journalists and technologists at The New York Times. Technologists contributing to data journalism may thus have gained access to, and learned how to visualize, data on a specific topic. Following this, journalists may pursue narrative articles that complement that data visualization.

Both internally and externally placed technological actants have significance for the selection/filtering of news. Moreover, technological actants may also be programmed to allow for audiences to actively publish items themselves. Most research suggests that news media have done little to enable audiences to craft articles in their own right (Singer et al. 2011). A Swedish case study on the social shaping of a mobile news application found that journalists, supported by technologists, won ground for a traditional and producer-centric approach in which the technological actant mainly served the purpose of technology-led repurposing and customization. The proposal for a participation-centric application by the businesspeople, in which the actant would make it possible for active audiences to select/filter stories for publishing, was thus turned down (Westlund 2012).

\section{Processing/Editing}

Manual modes of editing by journalists have dominated the routines of legacy news media, contributing to a path-dependent and institutionalized practice of manual remediation in digital journalism. This is a core stage of the news production process in which journalists typically do not allow audiences to take part. Moreover, little attention has been given to the fact that technology has become an ever-present part of processing/editing activities in journalism. Perhaps this is because the technological actants facilitating processing/editing, such as editorial CMS, have become institutionalized, naturalized, and even taken for granted. Similarly to electricity, time, and mobiles, such actants are largely invisible as long as they function as expected (Ling 2012). Internally situated actants facilitate interaction between humans and machines, through which journalists feed in news content for publishing. Many media companies, owning numerous newspaper titles, have in recent years invested in technologists and technological systems to facilitate the processing/editing of digital journalism through templates, reducing their need for human labor. Importantly, such technological actants are also being offered by external providers. Moreover, so-called 
responsive Web design (e.g., HTML5) has gained traction, whereby technological actants adapt content and visual elements to fit the affordances of mobile and desktop screens. Such strategies for technology-led activities that facilitate customization come with little need for intervention by human actors (cf., Westlund 2013).

\section{Distribution}

Distinct groups of digital publics are assembled according to human and algorithmic determinations: judgments, whether manual or computational in nature, about who receives what kind of information and through which modes of delivery. The issue of media distribution has often been lost amid scholarly emphases on production or consumption (Braun 2013). Journalism literature, however, has acknowledged the primacy that editors have in directing patterns of news distribution. Nevertheless, because distribution platforms are a strategic managerial issue, businesspeople are reasonably taking part in shaping the conditions for news distribution.

Building further on the above, we also argue that technologists and both internally and externally placed actants play a role in this stage of cross-media news work. Externally situated technological actants, such as Flipboard, Digg, Google News, and Facebook's Paper, facilitate re-distribution or re-publishing of news. Social media likewise have gained a major role in the distribution and re-distribution of news, opening new ways for traffic in and out from the digital news platforms.

This has meant a loss of professional control over editorial content (Lewis 2012), as news information-and some of the discussion around it-becomes detached from its creator. It likewise has meant a commercial loss, as other stakeholders benefit from audience traffic and advertising revenue, in addition to the news media that invested in its production. Technologists may take part in the distribution stage by translating journalistic values into programming code-in a sense, directing technological actants to behave, to the extent possible, as if they were human journalists. Westlund (2011) found such processes taking place when technologists and journalists at Göteborgs-Posten determined how technological actants were to be employed for publishing across digital and mobile platforms. Packaging and presentation (e.g., location-sensitive or personalized news publishing) were seen as facilitating value-added and customized experiences for audiences. Finally, looking at the audience aspect of distribution, audience metrics allow for tracing audiences for different purposes. When using systems for authentication (personal login), news media can take advantage of greater awareness about individuals, their social connections online, and the audience collectively to redirect to distinct individuals a series of news recommendations. Such actants that support customization and personalization of news distribution carry the potential for making news a more enjoyable experience-and yet raise corresponding concerns about a loss of shared knowledge.

\section{Interpretation}

Interpretation is the only stage at which Domingo et al. (2008) found that news media were meaningfully allowing audiences to participate-namely, by commenting on news stories and discussing public issues in forum spaces. The emphasis at this stage typically is about the relationship between journalists producing news and audiences 
actively responding to it (Singer et al. 2011). However, audiences as recipients may also take part in this stage, through their meaning-making (Bolin 2012) and socializing about the news, even when such engagement takes place through non-mediated conversations.

In the literature, businesspeople and technologists do not appear to play a significant part in this stage-though perhaps that is because their potential role in negotiating the interpretation of news has neither been clarified nor studied adequately. For example, a news innovation contest recently encouraged technologists to develop ideas for re-imagining dynamic spaces for online news discussion; the resulting entries suggested the potential for new tools (actants) that might facilitate a more civil, cohesive, and diverse discourse (Zamith and Lewis 2014). While the nature of interpretation by technological actants has received little attention in the literature, our matrix suggests that internal and external actants help shape the reception of media content simply by the way they shape initial and subsequent forms of (re)distribution to audiences across a proliferating range of mobile applications, aggregation websites, and customized email alerts (see above). Future research, however, is needed to assess the degree to which technological actants and their particular channels/platforms/algorithms are connected to particular interpretations of news by particular audiences.

\section{Conclusion}

The scholarly study of contemporary journalism, and cross-media news work specifically, is a complicated endeavor. The roles, boundaries, and processes of key elements of news work become increasingly hard to detect apart from other components in the same system. Traditional theories and concepts for unpacking journalism can take scholars only so far; what remains needed is a more comprehensive framework through which to account for the full array of actors, actants, audiences, and activities in crossmedia news work. By adding a sociotechnical element to the sociocultural perspective of mainline research in journalism studies, this approach may help reveal new insights into the relationships among human actors inside the organization, human actors and audiences beyond it, and the nonhuman actants that cross-mediate their interplay. This approach better acknowledges how journalism is becoming interconnected with technological tools, processes, and ways of thinking.

In articulating what a sociotechnical emphasis might look like in future research, our key intervention has been to offer not only a conceptualization of the Four A'sactors, actants, audiences, and activities-but also a matrix through which to visualize their associations. This conceptual matrix can guide future empirical research, which in turn may reconfigure and/or strengthen the assessment of how actors, actants and audiences take part in journalistic activities. Preferably this would be done longitudinally, assessing not only actors' distinct practices but also their perceptions of one another as well as their complex perceptions of actants and audiences (as recipients, commodities, and active participants). While acknowledging that such an ambition may be hard to accomplish in a single study, we argue that the mere awareness of that wider view on cross-media news work would inform better-developed research questions, research designs, and ultimate contributions to the literature on journalism and technology. In relation to this, we propose that future research conceptualize and study a sixth stage in 
news production called analysis, in addition to the five proposed by Domingo et al. (2008). Analysis would represent forms of feedback and organizational learning that loop back to the first stage, and involve actors, actants, and audiences in combination.

Future research might more thoroughly review, synthesize, and develop models for journalism, of which there are relatively few emphasizing the distinct interplay of and tension between human and technology, or manual and computational modes of orientation and output (see Westlund 2013). Finally, there are opportunities for informing news management and journalism education through a more comprehensive accounting of cross-media news work as a system of actors, actants, and audiences engaged in a complex set of media activities - each activity and ensemble of actors, actants, and audiences carrying with them key implications and concerns for business/commercial and professional/normative interests alike. 


\section{Notes}

1. Notably, in choosing sociotechnical as a framing, we acknowledge and yet depart from the sociotechnical systems perspective, which is more appropriate for studying field-level dynamics (Fortunati and Sarria 2010).

2. We are grateful to Matt Powers for helping us articulate this point.

\section{Acknowledgements}

The authors gratefully acknowledge comments on this paper from Joshua Braun, Matt Powers, Jen Schradie, Rodrigo Zamith, anonymous review, and special issue editors Steen Steensen and Laura Ahva.

\section{References}

Aitamurto, Tanja, and Seth C. Lewis. 2013. "Open Innovation in Digital Journalism: Examining the Impact of Open APIs at Four News Organizations." New Media \& Society 15 (2): 314-331. doi:10.1177/1461444812450682.

Ananny, Mike. 2013. "Press-Public Collaboration as Infrastructure: Tracing News Organizations and Programming Publics in Application Programming Interfaces." American Behavioral Scientist 57 (5): 623-642. doi:10.1177/0002764212469363.

Anderson, C. W. 2011. "Deliberative, Agonistic, and Algorithmic Audiences: Journalism's Vision of its Public in an Age of Audience Transparency." International Journal of Communication 5 (0): 529-547. ISSN 1932-8036. Available at: $<$ http://ijoc.org/index.php/ijoc/article/view/884>.

Anderson, C. W. 2012. "Towards a Sociology of Computational and Algorithmic Journalism." New Media \& Society 15 (7): 1005-1021. doi:10.1177/1461444812465137.

Anderson, C. W. 2013. Rebuilding the News: Metropolitan Journalism in the Digital Age. Philadelphia: Temple University Press.

Bakker, Piet. 2012. "Aggregation, Content Farms and Huffinization: The Rise of Low-Pay and No-Pay Journalism." Journalism Practice 6 (5-6): 627-637. doi:10.1080/17512786.2012.667266.

Boczkowski, Pablo J. 2004. Digitizing the News: Innovation in Online Newspapers. Cambridge, MA: MIT Press.

Boczkowski, Pablo J., and Eugenia Mitchelstein. 2013. The News Gap: When the Information Preferences of the Media and the Public Diverge. Cambridge, Massachusetts: The MIT Press.

Bolin, Göran. 2012. "The Labour of Media Use: The Two Active Audiences." Information, Communication \& Society 15 (6): 796-814. doi:10.1080/1369118X.2012.677052.

Braun, Joshua. 2013. "Going Over the Top: Online Television Distribution as Sociotechnical System." Communication, Culture \& Critique 6 (3): 432-458. doi:10.1111/cccr.12015.

Bruns, Axel. 2008. Blogs, Wikipedia, Second Life, and Beyond: From Production to Produsage. New York: Peter Lang. 
Bruns, Axel. 2012. "Reconciling Community and Commerce? Collaboration between Produsage Communities and Commercial Operators." Information, Communication \& Society 15 (6): 815-835.

Couldry, Nick. 2008. "Actor Network Theory and Media: Do They Connect and on What Terms?" In Connectivity, Networks and Flows, edited by Andreas Hepp, Friedrich Krotz, Shaun Moores, and Carsten Winter, 93-109. Cresskill, NJ: Hampton Press.

Couldry, Nick. 2012. Media, Society, World: Social Theory and Digital Media Practice. Cambridge: Polity.

Deuze, Mark. 2005. "What is Journalism? Professional Identity and Ideology of Journalists Reconsidered." Journalism 6 (4): 442-464. doi:10.1177/1464884905056815.

Deuze, Mark. 2007. Media Work. London: Polity Press.

Domingo, David, and Chris Paterson. Eds. 2011. Making Online News: Newsroom Ethnographies in the Second Decade of Internet Journalism. 2nd ed. New York: Peter Lang.

Domingo, David, Thorsten Quandt, Ari Heinonen, Steve Paulussen, Jane B. Singer, and Marina Vujnovic. 2008. "Participatory Journalism Practices in the Media and Beyond: An International Comparative Study of Initiatives in Online Newspapers." Journalism Practice 2 (3): 326-342. doi:10.1080/17512780802281065.

Fortunati, Leopoldina, and Mauro Sarrica. 2010. "The future of the press: Insights from the sociotechnical approach." The Information Society: An International Journal, 26(4), 247-255. doi:10.1080/01972243.2010.489500

Gans, Herbert J. 1979. Deciding What's News: A study of CBS Evening News, NBC Nightly News, Newsweek, and TIME. New York: Pantheon Books

Godbole, Namrata, Manja Srinivasaiah, and Steven Skiena. 2007. "Large-Scale Sentiment Analysis for News and Blogs." ICWSM 7.

Gynnild, Astrid. 2013. "Journalism Innovation Leads to Innovation Journalism: The Impact of Computational Exploration on Changing Mindsets." Journalism doi:10.1177/1464884913486393.

Hagen, Ingunn, and Janet Wasko. 2000. Consuming Audiences? Production and Reception in Media Research. New York: Hampton Press.

Hemmingway, Emma. 2008. Into the Newsroom: Exploring the Digital Production of Regional Television News. London: Routledge.

Hermida, Alfred. 2010. "Twittering the News: The Emergence of Ambient Journalism." Journalism Practice 4 (3): 297-308. doi:10.1080/17512781003640703.

Hermida, Alfred, Seth C. Lewis, and Rodrigo Zamith. 2014. "Sourcing the Arab Spring: A Case Study of Andy Carvin's Sources on Twitter During the Tunisian and Egyptian Revolutions." Journal of Computer-Mediated Communication 19 (3): 479-499. doi:10.1111/jcc4.12074

Jenkins, Henry, Sam Ford, and Joshua Green. 2012. Spreadable Media: Creating Value and Meaning in a Networked Culture. New York: NYU Press.

Karlsen, Joakim, and Eirik Stavelin. 2014. "Computational Journalism in Norwegian Newsrooms." Journalism Practice 8 (1): doi:10.1080/17512786.2013.813190.

Klinenberg, Eric. 2005. "Convergence: News Production in a Digital Age." The ANNALS of the American Academy of Political and Social Science 597 (1): 48-64. doi:10.1177/0002716204270346. 
Küng, Lucy. 2008. Strategic Management in the Media. London: Sage.

Latour, Bruno. 1987. Science in Action. Cambridge, MA: Harvard University Press.

Latour, Bruno. 2005. Reassembling the Social: An Introduction to Actor-Network-Theory. Oxford: Oxford University Press.

Lee-Wright, Peter. 2008. "Virtual News: BBC News at a 'Future Media and Technology' Crossroads." Convergence: The International Journal of Research into New Media Technologies 14 (3): 249-260. doi:10.1177/1354856508091079.

Lewis, Seth C. 2012. "The Tension between Professional Control and Open Participation: Journalism and its Boundaries." Information, Communication \& Society 15 (6): 836-866. doi:10.1080/1369118X.2012.674150.

Lewis, Seth C., and Nikki Usher. 2013. "Open Source and Journalism: Toward New Frameworks for Imagining News Innovation." Media, Culture \& Society 35 (5): 602619. doi:10.1177/0163443713485494.

Lewis, Seth C., Avery E. Holton, and Mark Coddington. 2014. "Reciprocal Journalism: Concept of Mutual Exchange Between Journalists and Audiences." Journalism Practice 8 (2): 229-241. doi:10.1080/17512786.2013.859840

Ling, Richard. 2012. Taken for Grantedness: The Embedding of Mobile Communication into Society. Cambridge: MIT Press.

Loosen, Wiebke, and Jan-Hinrik Schmidt. 2012. "(Re-)Discovering the Audience: The Relationship between Journalism and Audience in Networked Digital Media." Information, Communication \& Society $15 \quad$ (6): 867-887. doi:10.1080/1369118X.2012.665467.

Micó, Josep L., Pere Masip, and David Domingo. 2013. "To Wish Impossible Things: Convergence as a Process of Diffusion of Innovations in an Actor-Network." International Communication Gazette 75 (1): 118-137. doi:10.1177/1748048512461765.

Mitchelstein, Eugenia, and Pablo J. Boczkowski. 2009. "Between Tradition and Change: A Review of Recent Research on Online News Production." Journalism 10 (5): 562586. doi:10.1177/1464884909106533.

Napoli, Philip M. 2010. Audience Evolution: New Technologies and the Transformation of Media Audiences. New York: Columbia University Press.

Neff, Gina, Tim Jordan, Joshua McVeigh-Schultz, and Tarleton Gillespie. 2012. "Affordances, Technical Agency, and the Politics of Technologies of Cultural Production." Journal of Broadcasting \& Electronic Media 56 (2): 299-313. doi:10.1080/08838151.2012.678520.

Nielsen, Ramus K. 2012. "How Newspapers Began to Blog: Recognizing the Role of Technologists in Old Media Organizations' Development of New Media Technologies." Information, Communication \& Society 15 (6): 959-978. doi:10.1080/1369118X.2012.694898.

Parasie, Sylvain, and Eric Dagiral. 2013. "Data-Driven Journalism and the Public Good: 'Computer-Assisted-Reporters' and 'Programmer-Journalists' in Chicago." New Media \& Society 15 (6): 853-871. doi:10.1177/1461444812463345.

Picard, Robert G., and Oscar Westlund. 2012. "The Dynamic Innovation Learning Model: A Conceptualization of Media Innovation." Paper presented at the 10th World Media Economics and Management Conference, Thessaloniki, Greece, May 23-27.

Pinch, Trevor J., and Wiebe E. Bijker. 1984. "The Social Construction of Facts and 
Artefacts: Or How the Sociology of Science and the Sociology of Technology might Benefit Each Other." Social Studies of Science 14 (3): 399-441. doi:10.2307/285355.

Plesner, Ursula. 2009. "An Actor-Network Perspective on Changing Work Practices: Communication Technologies as Actants in Newswork." Journalism 10 (5): 604-626. doi:10.1177/1464884909106535.

Powers, Matthew. 2012. "In Forms that are Familiar and yet-to-be Invented': American Journalism and the Discourse of Technologically Specific Work." Journal of Communication Inquiry 36 (1): 24-43. doi:10.1177/0196859911426009.

Schmitz Weiss, Amy, and David Domingo. 2010. "Innovation Processes in Online Newsrooms as Actor-Networks and Communities of Practice." New Media \& Society 12 (7): 1156-1171. doi:10.1177/1461444809360400.

Shoemaker, Pamela J., and Timothy Vos. 2009. Gatekeeping Theory. New York: Routledge.

Singer, Jane B., David Domingo, Ari Heinonen, Alfred Hermida, Steve Paulussen, Thorsten Quandt, Zvi Reich, and Marina Vujnovic. 2011. Participatory Journalism: Guarding Open Gates at Online Newspapers. Malden, MA: Wiley-Blackwell.

Smythe, Dallas W. 1977. "Communications: Blindspot of Western Marxism." Canadian Journal of Political and Society Theory 1 (3): 1-28.

Steensen, Steen. 2011. "Online Journalism and the Promises of New Technology: A Critical Review and Look Ahead." Journalism Studies 12 (3): 311-327. doi:10.1080/1461670X.2010.501151.

Tuchman, Gaye. 1978. Making News: A Study in the Construction of Reality. New York: Free Press.

Turow, Joseph. 2011. The Daily You: How the New Advertising Industry Is Defining Your Identity and Your Worth. New Haven, CT: Yale University Press.

van Dalen, Arjen. 2012. "The Algorithms behind the Headlines: How Machine-Written News Redefines the Core Skills of Human Journalists." Journalism Practice 6 (5-6): 648-658. doi:10.1080/17512786.2012.667268.

van Dijck, José. 2009. "Users like you? Theorizing Agency in User-generated Content." Media Culture Society, 31 (1), 41-58. doi:10.1177/016344370809824.

Westley, Bruce H., and Malcolm S. MacLean. 1957. A Conceptual Model for Communications Research. Journalism \& Mass Communication Quarterly, 34 (1), 31-38. doi:10.1177/107769905703400103.

Westlund, Oscar. 2011. Cross-Media News Work: Sensemaking of the Mobile Media (R)evolution. Gothenburg: University of Gothenburg. https://gupea.ub.gu.se/bitstream/2077/28118/1/gupea_2077_28118_1.pdf

Westlund, Oscar. 2012. "Producer-Centric Vs. Participation-Centric: On the Shaping of Mobile Media." Northern Lights 10 (1): 107-121.

Westlund, Oscar. 2013. "Mobile News: A Review and Model of Journalism in an Age of Mobile Media." Digital Journalism 1 (1): 6-26. doi:10.1080/21670811.2012.74027.

Zamith, Rodrigo, and Seth C. Lewis. 2014. "From Public Spaces to Public Sphere: Rethinking Systems for Reader Comments on Online News Sites." Digital Journalism. doi:10.1080/21670811.2014.882066 


\section{Table 1. The Cross-Media News Work Matrix}

\begin{tabular}{|c|c|c|c|c|c|c|c|c|}
\hline & \multicolumn{3}{|c|}{ ACTORS } & \multicolumn{2}{|c|}{ ACTANTS } & \multicolumn{3}{|c|}{ AUDIENCES } \\
\hline & Journalists & Technologists & Businesspeople & Internal & External & Recipients & Active participants & Commodities \\
\hline Access/observation & Yes & Yes & No & Yes & Yes & No & Yes & No \\
\hline Selection/filtering & Yes & Yes & No & Yes & Yes & No & Yes & No \\
\hline Processing/editing & Yes & Yes & No & Yes & Yes & No & No & No \\
\hline Distribution & Yes & Yes & Yes & Yes & Yes & No & Yes & Yes \\
\hline Interpretation & Yes & Yes & No & Yes & Yes & Yes & Yes & No \\
\hline
\end{tabular}

Note: On the left are listed institutionalized communication functions, or activities, traditionally associated with news production (based on Domingo et al., 2008). Where the authors have determined that such activities might reasonably involve certain actors, technological actants, or audiences in the contemporary media environment, based on literature and contacts in the industry, they have been marked with "Yes." When such involvements are judged as not likely, albeit possible, they have been marked with "No." Ultimately, the final determination of such classifications requires empirical research; this is merely a conceptual starting point toward that end. 